\title{
Konsep Work Life Balance Terhadap Produktivitas Pegawai yang Menerapkan Work From Home Pada Masa Pendemi Covid-19 (Studi Literatur)
}

\author{
${ }^{1}$ Ahmad Saoki Andriyana, ${ }^{2}$ Supriansyah \\ Universitas Muhammadiyah Prof. DR. Hamka, Jakarta, Indonesia \\ Email: ${ }^{1}$ Saoki.andriyana10@gmail.com, ${ }^{2}$ Supriansyah@uhamka.ac.id
}

(Diterima: Juli 2021; Direvisi: Juli 2021; Dipublikasikan: September 2021)

\begin{abstract}
ABSTRAK
Pendemi Covid-19 di Indonesia menyebabkan perubahan yang amat besar dan memberikan dampak terutama dalam pelaksanaan bekerja dirumah (Work From Home) yang diharuskan oleh organisasi perusahaan. Pemberlakuan Work From Home dalam upaya memutus mata rantai penyebaran virus Covid-19 menimbulkan berbagai masalah seperti konflik keluarga, stres, distraksi konsentrasi serta sarana prasarana sebagai penunjang Work From Home yang menganggu produktivitas dan keseimbangan kehidupan pribadi. Oleh karena itu peneliti berniat untuk mengetahui konsep Work Life Balance terhadap produktivitas pegawai yang menerapkan Work From Home pada masa pendemi Covid-19. Metode penelitian ini adalah studi literatur yang didasarkan pada studi terdahulu dengan menyesuaikan kriteria yang sesuai dengan variabel yang diteliti. Pada penelitian ini didapat hasil bahwa konsep Work Life Balance dengan penggunaan waktu yang fleksibel, penerapan lingkungan yang baik, hubungan keluarga yang positif dan motivasi kerja dapat meningkatkan produktivitas pegawai yang menerapkan Work From Home.
\end{abstract}

Kata Kunci: Work Life Balance, Produktivitas, Work From Home 


\section{PENDAHULUAN}

Presiden Joko Widodo mengumumkan secara resmi kasus pertama Covid-19 di Indonesia tanggal 2 Maret 2020. Dua warga negara Indonesia yang positif Covid19 tersebut mengadakan kontak dengan warga negara Jepang yang datang ke Indonesia. WHO lalu menghimbau agar warga dunia menerapkan social distancing dan physical distancing, yaitu menjaga jarak sosial secara fisik dengan orang lain untuk mencegah peneybaran virus Corona. Negara-negara yang terkena virus ini menerapkan karantina dan lockdown yaitu menutup semua akses jalan, bandara, pelabuhan, serta tempat-tempat umum yaitu sekolah, kantor, pusat perbelanjaan, pusat hiburan, kafe, dan restoran. Selain itu juga negaranegara yang terkena imbas penularan juga menerapkan kebijakan Work From Home (bekerja dari rumah) pada para pegawai agar memutus rantai penyebaran virus Corona $(\mathrm{CNN}$ Indonesia, 2020)

Data BPS per 1 Juni 2020 mencatat $39,09 \%$ sejumlah pekerja melaksanakan WFH sejak awal ditetpakan pendemi, sementara $34,76 \%$ lainnya bekerja dari rumah dengan kombinasi harus ke kantor beberapa waktu. Sementara temuan survei dari Word Economic Forum menyebut $91,7 \%$ perusahaan di Indonesia menerapkan WFH(Yoshio, 2020).

Namun dalam pelaksanaannya, WFH masih menuai banyak problematika. (Mungkasa, 2020) menyatakan bahwa pegawai yang melaksanakan pekerjaan dirumah seringkali tidak memiliki fasilitas ataupun suasana bekerja yang sama dengan kantor. Agar pekerjaan lancar, baik pimpinan maupun pegawai perlu menyadari beberapa tantangan dan gangguan. Diantaranya gangguan yang berasal dari orang rumah (distraksi konsentrasi), gangguan teknis, sarana dan prasarana yang kurang mumpuni, komunikasi tidak efektif, waktu atau pembatasan jam kerja yang tidak terjadwal, komunikasi kurang efektif antara tim kerja dan gangguan kesehatan. Dimana masalah itu dapat menghambat produktivitas Work From Home

Pernyataan diatas juga selaras dengan (William, 2020) bahwa lingkungan kerja mempengaruhi produktivitas kerja. Hasil; Berdasarkan nilai signifikansi pada nilai Sig <0,05 maka $\mathrm{H}$ bahwa "Lingkungan kerja dapat mempengaruhi produktivitas karyawan" dapat diterima. nilai $\mathrm{t}$ hitung $(6,138)>\mathrm{t}$ tabel $(1,6657)$ berdasarkan variabel lingkungan kerja dapat dikatakan berpengaruh positif terhadap variabel produktivitas kerja. Artinya jika lingkungan kerja membaik maka produktivitas juga akan meningkat.

(Ma'rifah, 2020) bekerja dari rumah (WFH) sebagai konsep flexible working tidak serta merta meningkatkan produktivitas pegawai yang selanjutnya dapat berdampak pada produktivitas organisasi.

Permasalahan WFH tidak hanya berimpikasi terhadap produktivitas, tetapi juga berimplikasi terhadap Work Life Balance, (Maria, 2020) menyatakan bahwa Work From Home memiliki pengaruh terhadap Work Life Balance yaitu dapat menimbulkan konflik antara 
kehidupan pekerjaan dan kepentingan keluarga.

Work Life Balance dijelaskan dalam riset (Delecta, 2011) adalah sebagai kemampuan sesorang atau individu untuk memenuhi tugas dalam pekerjaannya dan tetap berkomitmen pada keluarga mereka bertanggung jawab diluar pekerjaan lainnya. Oleh karena itu, perusahaan tempat bekerja diharapkan membangun Work Life Balance agar pekerja atau pegawai dapat menyeimbangkan peran gandanya dan bekerja secara profesional agar keseimbangan kehidupan kerja dapat terlealisasi dengan baik. Konsep kerja seperti ini akan memberikan dampak positif jika organisasi menerapkan pada individu yang tepat.

Berdasarkan paparan diatas, dalam pelaksanaan Work From Home pada masa pendemi, banyak pekerja didalam penelitian sebelumnya yang merasakan problematika saat bekerja dirumah. Diantaranya, terganggunya hubungan keluarga, distraksi konsentrasi, sosial, sarana prasaran yang tidak mempuni . Maka dari itu penelitian ini bertujuan untuk melihat solusi dari berbagai problematika yang berkenaan dengan peningkatan produktivitas pegawai melalui telaah secara ilmiah Konsep Work Life Balance Terhadap Produktivitas Pegawai yang Menerapkan Work From Home Pada Masa Pendemi Covid-19

\section{TINJAUAN PUSTAKA}

\section{Work From Home (Bekerja Dari Rumah)}

Work From Home menurut (Foreman, 2015), bukanlah seperti kita bebas dari pekerjaan, tapi merasakan kenyamanan bekerja di lingkungan rumah. Maknanya lebih kepada melakukan proses pekerjaan di lingkungan rumah, dapat juga dalam bentuk melakukan penjualan barang dan jasa diluar kantor. (Foreman,2015) juga menambahkan bahwa meskipun melakukan pekerjaan dari rumah untuk mendapatkan hasil yang memuaskan pasti memakan waktu dan mendapatkan tekanan dalam bekerja. (Paul, 2018) mengatakan, bahwa dengan Work From Home seseorang dapat memanfaatkan kemampuannya dimanapun berada tanpa terkait dengan masalah tempat bekerja, Maka dengan Work From Home sebuah perusahaan akan berpuluang mendapatkan tenaga kerja yang bergam, berjangka panjang, dan tentunya mengntungkan biaya bagi perusahaan. (Hynes, 2015) menyebut Work From Home sebagai telework, secara sederhana menyatakan bahwa Work From Home merupakan kegiatan bekerja yang dilakukan di rumah. Telework dilaksanakan ketika teknologi dapat mempermudah pekerjaan tanpa mempermasalahkan jarak ke tempat bekerja. (Gadecki, 2018) mengatakan istilah Work From Home sebagai work at home yang merupakan kondisi dimana seseorang dalam bekerja mengalami dua ranah yaitu dunia pekerjaan yang bersifat publik dan kepentingan keluarga yang menjadi urusan pribadi.

(Gadecki, 2018) mengatakan ada tiga dimensi yang mewujudkan Work From Home di anataranya sebagai berikut : 
a. Ruang: Transformasi ruang pribadi rumah (sebagai tempat realisasi kesukaan dan mengeperesikan diri) kedalam ruang publik semu.

b. Waktu: pengunaan ruang pribadi oleh ruang kerja yang mengarah kepada tabrakan dua arah yang berbeda sistem waktu yaitu waktu pekerjaan rumah tangga dan waktu tugas profesional yang tumpang tindih.

c. Peran sosial. Narasi tentang diri sendiri sebagai pekerja dari rumah, sebuah emansi peran dan posisi teleworker yang konstan dilakukan.

\section{Produktivitas}

Produktivitas memeiliki peranan yang sangat penting dalam menjalankan aktivitas pekerjaan. (Saleh \& Utomo, 2018) berpendapat bahwa produtivitas kerja karyawan adalah kemampuan memperoleh sebesar besarnya dari sarana prasarana yang tersedia dengan menghasilkan input dan output yang optimal.(Simarmata, 2020) produktivitas adalah sebuah ukuran dari efesiensi serta perbandingan antara output yang berupa jasa atau barang dengan input yang berupa uang, bahan sumber daya manusia. Untuk mengkur produktivitas (Simarmata, 2020) dengan indikator sebagai berikut :

a. kemampuan dari individu dilihat dari keterampilan yang dimiliki serta profesionalitas dalam bekerja

b. selalu meningkatkan hasil pencapaian dalam bekerja.

c. semangat kerja untuk menjadi lenih baik.

d. Pengembangan diri untuk meningkatkan profesionalitas dalam bekerja.

e. Mutu, dimana kualitas kerja pegawai dapat dikatakan mutu. Tujuajnya untuk individu dan organisasi

f. Efesiensi, hal ini dapat dilihat dengan membandingkan hasil yang dipreloleh dengan sumber daya yang digunakan secara menyeluruh

3. Work Life

(Keseimbangan Kerja)

Work Life Balance menurut

(Kelliher et al., 2019) keseimbangan kehidupan kerja mengacu pada hubungan antara aspek pekerjaan dan nonpekerjaan dari kehidupan individu dimana mencapai keseimbangan kehidupan kerja yang memuaskan dan dipahami sebagai pembatasan satu sisi (bekerja) untuk memiliki lebih banyak waktu untuk yang lain. (Brough et al., 2020) mendefinisikan Work Life Balance sebuah fokus yang bergerak pada pekerjaan dan keluarga, yang mencakup berbagai tuntutan pekerjaan dan kehidupan lainnya.

Dimensi Work Life Balance Menurut Fisher dalam (adhiningtiyas, 2016) mengatakan ada 4 golongan dimensi yang menjadi pengembangan alat ukur tersebut : 
a. WIPL (Work Interfence With Personal Life). Dimensi ini mengacu pada sejauh manakah kehidupan pekerjaan mengganggu kehidupan pribadi. Misalnya, apabila seseorang mempunyai masalah dalam kehidupan pribadinya, hal tersebut dapat menganggu kinerja pribadi pada saat bekerja.

b. PLIW (Personal Life interference With Work). Dimensi ini mengacu pada sejauh makanakah pekerjaan menganggu kehidupan pribadi.

c. PLEW (Personal Life Enchancement of Work). Dimensi ini mengacu sejauh manakah kehidupan pribadi seseorang dapat meningkatkan motivasi pribadi dalam bekerja.

d. WEPL (Work Enchancement Of Personal Life). Dimensi ini mengacu pada sejauh manakah pekerjaan dapat meningkatkan kualitas kehidupan pribadi.

\section{METODE PENELITIAN}

Metode yang digunakan dalam penelitian ini adalah studi studi literatur. Jenis data yang dikumpulkan berupa data sekunder berupa hasil penelitian dari berbagai artikel, sumber pustaka dan dokumen yang sesuai dengan tema (Arizona et al., 2020)

Tabel 1. Artikel Ilmiah

\begin{tabular}{|c|c|c|c|}
\hline No. & Peneliti, Tahun, Jurnal & Judul & Variabel \\
\hline 1. & $\begin{array}{c}\text { (Ganapathi, 2016), } \\
\text { Jurnal Ecodomia }\end{array}$ & $\begin{array}{c}\text { Pengaruh Work Life Balance terhadap } \\
\text { Kepuasan Kerja Karyawann }\end{array}$ & $\begin{array}{c}\text { Work Life Balance; } \\
\text { Kepuasan Kerja } \\
\text { Karyawann }\end{array}$ \\
\hline 2. & $\begin{array}{c}\text { (Ma'rifah, 2020), } \\
\text { Jurnal Civil Service }\end{array}$ & $\begin{array}{c}\text { Implemnetasi Work From Home : kajian } \\
\text { tentang dampak positif dampak negatif } \\
\text { dan produktivitas pegawai }\end{array}$ & $\begin{array}{c}\text { Work From Home; } \\
\text { produktivitas } \\
\text { pegawai }\end{array}$ \\
\hline 3. & $\begin{array}{c}\text { (Ishak \& } \\
\text { Mangundjaya, 2020), }\end{array}$ & $\begin{array}{c}\text { Pengelolaan stres dan peningkatan } \\
\text { produktivitas kerja selama Work From } \\
\text { Home pada masa pandemi covid-19 }\end{array}$ & $\begin{array}{c}\text { Peningkatan } \\
\text { produktivitas kerja; } \\
\text { Work From Home }\end{array}$ \\
\hline
\end{tabular}

Penerapan dalam studi literatur ini dibagi menjadi beberapa tahapan

1. Menentukan topik dan konsentrasi yang akan menjadi fokus penelitian sehingga dapat merumuskan judul penelitan. Selain itu peneliti mendeskripsikan urgensi dan novelty topik penelitan yang akan diteliti. Selanjutnya peneliti dapat merumuskan masalah dan tujuan yang ingin dicapai

2. Melakukan proses pencarian kepustakaan dengan dengan menggunakan kata kunci yang relevan dengan variabel topik penelitian. Literatur dapat dicari melalui berbagai sumber yang tersedia secara cetak maupun elektronik. Setelah literatur terkumpul, kemudian dilakukan proses analisis.

Pengumpulan literatur ini dilakukan sejak Februari 2021. Pencarian menggunakan Google Cendekia dengan menggunakan kata kunci yaitu Work Life Balance, produktivitas pegawai selama Work From Home dan studi literatur. Adapun artikel yang digunakan dalam penelitian ini berjumlah 14 artikel sebagai berikut : 


\begin{tabular}{|c|c|c|c|}
\hline & $\begin{array}{c}\text { Jurnal Psikologi } \\
\text { Udayana }\end{array}$ & & \\
\hline 4. & $\begin{array}{l}\text { (Maria, 2020), jurnal } \\
\text { JMBI UNSRAT }\end{array}$ & $\begin{array}{c}\text { Pengaruh Work From Home Terhadap } \\
\text { Work Life Balance Pekerja Perempuan } \\
\text { di Kota Ende }\end{array}$ & $\begin{array}{l}\text { Work From Home, } \\
\text { Work Life Balance }\end{array}$ \\
\hline 5. & $\begin{array}{c}\text { (Ashal, 2020), Jurnal } \\
\text { ilmiah Kebijakan } \\
\text { Hukum } \\
\end{array}$ & $\begin{array}{l}\text { Pengaruh Work From Home Terhadap } \\
\text { Kinerja Aparatul Sipil Negara di Kantor } \\
\text { imigrasi Kelas I Khusus TPI Medan }\end{array}$ & $\begin{array}{c}\text { Work From Home, } \\
\text { Kinerja }\end{array}$ \\
\hline 6. & $\begin{array}{c}\text { (Gadecki, 2018), } \\
\text { Jurnal Studia } \\
\text { humanistyczne AGH }\end{array}$ & $\begin{array}{l}\text { New Technologies And Family Life In } \\
\text { The Context Of Work At Home The } \\
\text { Strategies Of Work Life Balance }\end{array}$ & $\begin{array}{l}\text { Tecnhologies, Work } \\
\text { From Home, Work } \\
\text { Life Balance }\end{array}$ \\
\hline 7. & $\begin{array}{c}\text { (Mungkasa, 2020) } \\
\text { Jurnal Perencanaan } \\
\text { Pembangunan }\end{array}$ & $\begin{array}{c}\text { Bekerja Dari Rumah (Working From } \\
\text { Home/WFH): Menuju tatanan Baru Era } \\
\text { Pendemi COVID } 19\end{array}$ & Work From Home \\
\hline 8. & $\begin{array}{l}\text { (Wahyuningsih, 2021) } \\
\text { Jurnal Teknikdan } \\
\text { Keselamatan } \\
\text { Transportasi }\end{array}$ & $\begin{array}{c}\text { Persepsi pegawai Terhadap Work From } \\
\text { Home di Politeknik Penerbangan } \\
\text { Makasar }\end{array}$ & $\begin{array}{l}\text { Persepsi Pegawai, } \\
\text { Work From Home }\end{array}$ \\
\hline 9. & $\begin{array}{l}\text { (Simarmata, 2020), } \\
\text { Jurnal Ekonomi dan } \\
\text { Humaniora }\end{array}$ & $\begin{array}{c}\text { Pengaruh Work From Home Terhadap } \\
\text { Produktivitas Dosen Politeknik Negeri } \\
\text { Ambon }\end{array}$ & $\begin{array}{l}\text { Work From Home, } \\
\text { Produktivitas }\end{array}$ \\
\hline 10. & $\begin{array}{l}\text { (Saina et al., 2016), } \\
\text { Jurnal Administrasi } \\
\text { UNSRAT }\end{array}$ & $\begin{array}{c}\text { Pengaruh Work Life Balance dan } \\
\text { Kompensasi Terhadap Kinerja } \\
\text { Karyawan pada PT PLN (Persero) } \\
\text { wilayah Sulutenggo Area Manado }\end{array}$ & $\begin{array}{l}\text { Work Life Balance, } \\
\text { Kompensasi, } \\
\text { Kinerja }\end{array}$ \\
\hline 11. & $\begin{array}{l}\text { (Sarikit, 2017) Jurnal } \\
\text { Manajemen } \\
\text { pendidikan }\end{array}$ & $\begin{array}{c}\text { Pengaruh Work Life Balance dan } \\
\text { Keterikatan Pegawai Terhadap Kinerja } \\
\text { Pegawai Fakultas Ilmu Sosial dan Ilmu } \\
\text { Politik Universitas Indonesia }\end{array}$ & $\begin{array}{c}\text { Work Life Balance, } \\
\text { Kinerja }\end{array}$ \\
\hline 12. & $\begin{array}{c}\text { (Weerakkody \& } \\
\text { Mendis, 2017), } \\
\text { Journal Of Human } \\
\text { Resource } \\
\text { Management } \\
\end{array}$ & $\begin{array}{c}\text { The Impact of Work Life Balance on } \\
\text { Employee Performance with Reference } \\
\text { to Telecommunication Industry in Sri } \\
\text { Lanka: A Mediation Model }\end{array}$ & $\begin{array}{l}\text { Work Life Balance, } \\
\text { Employee } \\
\text { Performance }\end{array}$ \\
\hline 13. & $\begin{array}{c}\text { (Rene, 2018), Jurnal } \\
\text { Manajemen bisnis } \\
\text { Sriwijaya }\end{array}$ & $\begin{array}{l}\text { Pengaruh Work Life Balance Terhadap } \\
\text { Komkitmen Organisasi, Kepuasan } \\
\text { Kerja, dan Motivasi Kerja Terhadap } \\
\text { Kinerja Individu Pada Karyawan } \\
\text { Perusahaan Asuransi di Jakarta }\end{array}$ & $\begin{array}{c}\text { Work Life Balance, } \\
\text { Kinerja }\end{array}$ \\
\hline 14. & $\begin{array}{l}\text { (Rodhiyatu Aliya \& } \\
\text { Saragih, 2020) Jurnal } \\
\text { Ilmia MEA }\end{array}$ & $\begin{array}{c}\text { Pengaruh Work Life Balance dan } \\
\text { Lingkungan Kerja Terhadap Kepuasaan } \\
\text { Kerja Karyawan di PT Telkom Divisi } \\
\text { Regional III Jawa Barat }\end{array}$ & $\begin{array}{l}\text { Work Life Balance, } \\
\text { Lingkungan } \\
\text { Kerja,Kepuasan } \\
\text { Kerja }\end{array}$ \\
\hline
\end{tabular}

\section{HASIL PENELITAN}

Konsep Work Life Balance Terhadap Produktivitas Pegawai yang Menerapkan Work From Home Pada Masa Pendemi Covid-19 penting untuk dikaji saat ini (Ganapathi, 2016) dalam penelitiannya memberikan gambaran penting dalam menerapkan keseibangan kehidupan kerja seperti waktu kerja yang fleksibel perlu diberlakukan dengan tujuan agar pegawai dapat menjalankan aktivitas lain di luar pekerjaan seperti keperluan pribadi, keluarga, hobi. Dengan adanya penerapan konsep Work Life Balance 
dapat meningkatkan kualitas dalam bekerja. hal ini juga sejalan dengan penelitian (Maria, 2020) dalam penelitiannya mengatakan kunci dari menjaga keseimbangan kehidupan pekerjaan dan keluarga adalah pada pengelolaan waktu dan menimbang kebutuhan, selain itu dukungan anggota keluarga untuk memberi ruang dan waktu yang lebih fleksibel bagi pegawai perempuan tentunya untuk menjalankan peran ganda juga berperan penting dalam menjaga kulitas keseimbangan, keharmonisan keluarga dan pekerjaan. (Ashal, 2020) dalam penelitiannya juga menyaran kan agar waktu pada saat bekerja dirumah tetap produktiv yaitu menyusun jam kerja secara teratur, merencanakan alur kerja pribadi dan mengatur jam istirahat sesuai kebutuhan . Pernyataan diatas sesuai dengan dimensi yang ditakatakan (Gadecki, 2018) bahwa pengunaan ruang pribadi oleh ruang kerja yang mengarah kepada tabrakan dua arah yang berbeda sistem waktu yaitu waktu pekerjaan rumah tangga dan waktu tugas profesional yang tumpang tindih.

Selain itu tidak hanya masalah pembagian waktu saja tetapi juga masalah sarana dan prasarana yang tidak mempuni dimana sarana prasarana itu untuk menunjang pekerjaan pada saat Work From Home. (Mungkasa, 2020) dalam penelitianya mengatakan bahwa untuk menunjang kinerja pegawai pada saat bekerjaa dirumah tentunya dibutuhkan perangkat pendukung seperti laptop, printer dan internet, dimana, internet ini sangat penting untuk komunikasi dengan tim kerja agar komunikasi berjalan dengan efektif. Pernyataan ini juga didukung
(Wahyuningsih, 2021) dan (Simarmata, 2020) mengatakan bahwa pentingnya internet pada saat Work From Home untuk kelancaran pekerjaan dan komunikasi yang lebih efektivf dengan sesama pegawai.

Ruangan atau lingkungan untuk bekerja dirumah juga sangat penting untuk menjaga kesetabilan saat bekerja dirumah (Simarmata, 2020) dalam penelitiannya juga menyarankan agar pegawai yang bekerja dirumah memiliki lingkungan yang fleksibel. Penelitian ini serupa dengan dimensi yang dikatakan (Gadecki, 2018) dalam (Maria, 2020) dimana transformasi ruang pribadi , rumah sebagai tempat realisasi kesukaan dan mengepresikan diri kedalam ruang publik semu. Dalam penelitiannya (Mungkasa, 2020) juga menyatakan bahawa dalam bekerja dirumah harus memperhatikan lingkungan fisik tidak lain yaitu ruangan bekerja agar kesehatan, keamanan, dan keamanan saat bekerja. pernyataan ini sejalan (Rodhiyatu Aliya \& Saragih, 2020) dalam penelitiannya mengatakan bahwa Work Life Balance dan Lingkungan Kerja berpengaruh positif terhadap kepuasan kerja pada pegawai. Hal ini didukung dengan lingkungan yang baik.

Selain masalah ruangan dan lingkungan kerja, perlu diperhatikan untuk permaslahan invidu pada saat bekerja dirumah agar kondisi kesehatan pekerja tetap terjaga dan mencapai Work Life Balance. (Ishak \& Mangundjaya, 2020) mengatakan bahwa pegawai yang bekerja selama masa pendemi berlangsung sebaiknya tetap melakukan strategi problem focused coping yang dapat meminimalisisr meningkatnya stres 
kerja dengan cara melakukan perencanaan kegiatan sehari-hari, menahan diri dari masalah, mencari dukungan sosial baik dari atasan, rekan kerja, maupun keluarga. Bantuan atau infomasi mengenai stresor yang muncul dan tetap konsentrasi saat bekerja demi menjaga produktivitas yang berujung pada pemenuhan harapan atau target kinerja dari organisasi tempat bekerja. hal ini juga didukung pernyataan (Saina et al., 2016) dengan hasil bahwa peningkatan produktivitas dalam menjalani kehidupan pribadi dan pekerjaan dikarenakan adanya keseimbangan antara keduanya Work Life Balance. Selain itu peran ini berdampak pada arah yang positif dalam meningkatkan kinerja karyawan. Penelitian ini ditunjukan bahwa pencapaian keseimbangan kehidupan pribadi dan pekerjaan akan tercapai jika karyawan tidak mengeluh dan stres akibat pekerjaan.pernyataan ini jug a didukung (Weerakkody \& Mendis, 2017) dalam penelitiannya mengatakan Work Life Balance dapat mencegah stress pada saat bekerja dan meningkatkan kebahagiaan.

Masalah saat Work From Home juga tidak hanya masalah teknis tetapi juga melibatkan peran keluarga agar Work Life Balance dapat tercapai (Maria, 2020) dalam penelitiannya mengatakan Work From Home memiliki pengaruh terhadap keseimbangan kehidupan pekerjaan. Yaitu, dapat menimbulkan konflik antara kehidupan pekerjaan dan kehidupan keluarga untuk menyeimbangkan kedua itu perlu adanya pengelolaan waktu, dukungan keluarga untuk menjaga kualitas Work Life Balance. pernyataan diatas juga serupa (Adhiningtiyas, 2016) dimana untuk mecapai Work Life Balance perlu adanya keseimbangan antara kehidupan pekerjaan dan kepentingan keluarga agar terhindar dari konflik dan menganggu pekerjaan. pernyataan diatas juga didukung (Fardianto \& Muzakki, 2020) dengan hasil bahwa dukungan keluarga juga berdampak positif terhadap pekerjaan, hal ini berdampak positif dalam keseimbangan kehidupan kerja (Work Life Balance) . tidak semata dukungan keluarga saja (Fatoni et al., 2021) juga menyatakan ketika dengan adanya keseimbangan antara berlibur dan bekerja dapat meningkatkan inovasi dan kreativitas pegawai serta terhindar dari kejenuhan. Inovasi lain yang harus dilakukan oleh individu agar Work Life Balance tercapai. Dukungan dari diri sendiri juga penting (Sarikit, 2017) menyatakan dalam penelitiaanya, seorang pegawai harus memiliki motivasi internal serta kecintaan terhadap pekerjaan yang dijalankan, sehingga pegawai dapat merasakan keikhlasan dan ketulusan terhadap profesi yang dijalankan. Pernyataan ini juga di dukung (Rene, 2018) dalam penelitiannya mengatakan dalam menerapkan Work Life Balance berpengaruh positif dan dapat mengkatkan kepuasan kerja, komitmen organisasi serta motivasi kerja.

\section{PENUTUP}

\section{Simpulan}

\begin{tabular}{lr}
\multicolumn{2}{c}{ Pegawai yang sedang } \\
menerapkan Work From & Home \\
selama pendemi Covid-19 rentan & rang \\
terhadap gangguan-ganguan yang \\
ditimbulkan oleh konflik keluarga, \\
distraksi konsentrasi, sarana-
\end{tabular} 
prasarana yang tidak mempuni dan gangguan waktu yang mengakibatkan stres pada saat bekerja. Perusahaan dan organisasi perlu memahami bahwa pegawai memerlukan penggunaan waktu yang fleksibel. Pegawai dengan konsep Work Life Balance dapat merasakan kepuasan kerja pada saat bekerja sehingga dapat meningkatkan produktivitas bekerja. dibuktikan dengan berbagai penelitian bahawa pegawai yang memiliki keseimbangan kehidupan kerja memiliki produktivitas yang lebih baik.

\section{Saran}

Berdasarakan kesimpulan,
peneliti mengajukan saran
dikarenakan keterbatasan data
penelitian terdahulu, maka sangat di
sarankan untuk meneliti lebih
mendalam mengenai konsep Work
Life Balance pada pegawai yang
menerapkan Work From Home
menggunakan data primer sehingga
menghasilakn data yang akurat sesuai
dengan karakteristik.

\section{DAFTAR PUSTAKA}

Adhiningtiyas. (2016). Work life balance index among technician. 2003, 327-333.

Arizona, K., Abidin, Z., \& Rumansyah, R. (2020). Pembelajaran Online Berbasis Proyek Salah Satu Solusi Kegiatan Belajar Mengajar Di Tengah Pandemi Covid-19. Jurnal Ilmiah Profesi Pendidikan, 5(1), 64-70. https://doi.org/10.29303/jipp.v $5 \mathrm{i} 1.111$

Ashal, R. A. (2020). Pengaruh Work From Home terhadap Kinerja Aparatur Sipil Negara di Kantor
Imigrasi Kelas I Khusus TPI Medan. Jurnal Ilmiah Kebijakan Hukum, 14(2), 223. https://doi.org/10.30641/kebija kan.2020.v14.223-242

Brough, P., Timms, C., Chan, X. W., \& Hawkes, A. (2020). Defining Work-life balance. Handbook of Socioeconomic Determinants of Occupational Health, 473487.

https://doi.org/10.1007/978-3030-31438-5

CNN Indonesia. (2020). Jokowi Umumkan Dua WNI Positif Corona di Indonesia. CNN Indonesia.

https://www.cnnindonesia.com /nasional/20200302111534-20479660/jokowi-umumkan-duawni-positif-corona-diindonesia

Delecta. (2011). Work Life Balance. 3, 186-189.

Fardianto, N. A., \& Muzakki. (2020). Support at work and home as a predictor of work life balance. Jurnal Manajemen Dan Bisnis Indonesia, 6(2), 144-153.

Fatoni, F., Indawati, N., Budiono, E., Kistyanto, A., \& Witjaksono, A. D. (2021). Pengaruh entrepreneurial leadership dan work life balance terhadap kinerja melalui inovasi saat work from home. Indonesian Journal of Economics, Entrepreneurship and Innovation, 1(3), 142-153. https://doi.org/10.31960/ijoeei. v1i3.858

Foreman, R. (2015). Legitimate Work from Home Jobs: The Complete Guide to Make Money Online from Home ( work from home ideas, tips ) $R$ 
ichard Foreman.

Gadecki. (2018). New Technologies and Family Life In The Context Of Work At Home The Strategies of Work Life Balance. 77-89.

Ganapathi, I. M. D. (2016). Pengaruh Work Life Balance Terhadap Kepuasan Kerja Karyawan (Studi pada PT. Bio Farma Persero). Fakultas Komunikasi Dan Bisnis, Universitas Telkom, IV(1), 125-135. http://www.researchgate.net/pu blication

Hynes, M. (2015). Telework Isn ' $t$ Working: A Policy Review Telework Isn' $t$ Working: A Policy Review. September.

Ishak, M., \& Mangundjaya, W. L. (2020). Pengelolaan stres dan peningkatan produktivitas kerja selama work from home pada masa pandemi covid-19. Jurnal Psikologi Udayana, 7(2), 93109.

https://doi.org/10.24843/JPU.2 020.v07.i02.p.09

Kelliher, C., Richardson, J., \& Boiarintseva, G. (2019). All of work? All of life? Reconceptualising work-life balance for the 21st century. Human Resource Management Journal, 29(2), 97-112. https://doi.org/10.1111/17488583.12215

Ma'rifah, D. (2020). Implementasi Work From Home: Kajian entang Dampak Positif, Dampak Negatif Dan Produktivitas Pegawai. Civil Service, 14(2), 53-64.

Maria. (2020). Pengaruh Work From Home dan Work Life Balance pada Pekerja Perempuan di
Kota Ende. 7(2), 247-258.

Mungkasa. (2020). Bekerja dari Rumah (Working From Home/WFH): Menuju Tatanan Baru Era Pandemi COVID 19. Jurnal Perencanaan Pembangunan: The Indonesian Journal of Development Planning, 4(2), 126-150. https://doi.org/10.36574/jpp.v4 i2.119

Paul. (2018). The Ultimate Guide To Working From Home. In Journal of Materials Processing Technology (Vol. 1, Issue http://dx.doi.org/10.1016/j.cirp. 2016.06.001\%0Ahttp://dx.doi. org/10.1016/j.powtec.2016.12. 055\%0Ahttps://doi.org/10.101 6/j.ijfatigue.2019.02.006\%0Ah ttps://doi.org/10.1016/j.matlet. 2019.04.024\%0Ahttps://doi.org /10.1016/j.matlet.2019.127252 \%0Ahttp://dx.doi.o

Rene, R. (2018). Pengaruh Work-Life Balance Terhadap Komitmen Organisasi , Kepuasan Kerja, Dan Motivasi Kerja. 16(4).

Rodhiyatu Aliya, G., \& Saragih, R. (2020). Pengaruh Work-Life Balance dan Lingkungan Kerja Terhadap Kepuasan Kerja Karyawan Di PT Telkom Divisi Telkom Regional III Jawa Barat. Jurnal Ilmiah MEA (Manajemen, Ekonomi, \& Akuntansi), 4(3), 84-95. http://journal.stiemb.ac.id/inde x.php/mea/article/view/291

Saina, I., Pio, R., \& Rumawas, W. (2016). Pengaruh Worklife Balance Dan Kompensasi Terhadap Kinerja Karyawan Pada Pt Pln (Persero) Wilayah Suluttenggo Area Manado. 
Jurnal Administrasi Bisnis UNSRAT, 4(3), 1-9. https://doi.org/10.35797/jab.4.3 .2016.12892.

Saleh, A. R., \& Utomo, H. (2018). Pengaruh Disiplin Kerja, Motivasi Kerja, Etos Kerja Dan Lingkungan Kerja Terhadap Produktivitas Kerja Karyawan Bagian Produksi Di Pt. Inko Java Semarang. Among Makarti, 11(1), 28-50. https://doi.org/10.52353/ama.v $11 \mathrm{i} 1.160$

Sarikit, M. (2017). Pengaruh Work Life Balance Dan Keterikatan Pegawai Terhadap Kinerja Pegawai Fakultas Ilmu Sosial Dan Ilmu Politik Universitas Indonesia. Jurnal Manajemen Pendidikan, $8(1), \quad 82$. https://doi.org/10.21009/jmp.0 8108

Simarmata, R. M. (2020). Pengaruh Work From Home Terhadap Produktivitas Dosen Politeknik Negeri Ambon. Intelektiva: Jurnal Ekonomi, Sosial Dan Humaniora, 02(01), 73-82.

Wahyuningsih, B. W., \& Makassar, P. P. (2021). Jurnal Teknik dan Keselamatan Transportasi Persepsi Pegawai Terhadap Work from Home di Politeknik
Penerbangan Makassar Employees ' Perceptions of Work from Home at the Aviation Polytechnic of Makassar. 4, 22-31.

Weerakkody, W. A. S., \& Mendis, M. D. V. S. (2017). The Impact of Work Life Balance on Employee Performance with Reference to Telecommunication Industry in Sri Lanka: A Mediation Model. Kelaniya Journal of Human Resource Management, 12(1), 72-100. https://orcid.org/00000003-3710-8528

William. (2020). Is There an Effect of Work Environment With Work Productivity on IT Employees? Is There an Effect of Work Environment With Work Productivity on IT Employees? Chrisna William. 1-5.

Yoshio, A. (2020). Survei: Work from Home Picu Jam Kerja Bertambah dan Kelelahan Mental - Nasional Katadata.co.id. Katadata.Co.Id. https://katadata.co.id/ariemega/ berita/5fa7cf815a0e8/surveiwork-from-home-picu-jamkerja-bertambah-dankelelahan-mental 